Article

\title{
Impact Assessment of Pollutant Emissions in the Atmosphere from a Power Plant over a Complex Terrain and under Unsteady Winds
}

\author{
Grazia Ghermandi *, Sara Fabbi, Barbara Arvani, Giorgio Veratti, Alessandro Bigi \\ and Sergio Teggi \\ Dipartimento di Ingegneria Enzo Ferrari, Università di Modena e Reggio Emilia, via P. Vivarelli 10, \\ 41125 Modena, Italy; sara.fabbi@unimore.it (S.F.); barbara.arvani@unimore.it (B.A.); \\ giorgio.veratti@unimore.it (G.V.); alessandro.bigi@unimore.it (A.B.); sergio.teggi@unimore.it (S.T.) \\ * Correspondence: grazia.ghermandi@unimore.it; Tel.: +39-059-205-6120
}

Received: 4 October 2017; Accepted: 7 November 2017; Published: 11 November 2017

\begin{abstract}
The development of a natural gas-fired tri-generation power plant (520 MW Combined Cycle Gas Turbines + 58 MW Tri-generation) in the Republic of San Marino, a small independent country in Northern Italy, is under assessment. This work investigates the impact of atmospheric emissions of $\mathrm{NO}_{x}$ by the plant, under the Italian and European regulatory framework. The impact assessment was performed by the means of the Aria Industry package, including the 3D Lagrangian stochastic particle dispersion model SPRAY, the diagnostic meteorological model SWIFT, and the turbulence model SURFPRO (Aria Technologies, France, and Arianet, Italy). The Republic of San Marino is almost completely mountainous, $10 \mathrm{~km}$ west of the Adriatic Sea and affected by land-sea breeze circulation. SPRAY is suitable for simulations under non-homogenous and non-stationary conditions, over a complex topography. The emission scenario included both a worst-case meteorological condition and three 10-day periods representative of typical atmospheric conditions for 2014. The simulated $\mathrm{NO}_{x}$ concentrations were compared with the regulatory air quality limits. Notwithstanding the high emission rate, the simulation showed a spatially confined environmental impact, with only a single $\mathrm{NO}_{x}$ peak at ground where the plume hits the hillside of the Mount Titano (749 $\mathrm{m}$ a.s.l.), $5 \mathrm{~km}$ west of the future power plant.
\end{abstract}

Keywords: dispersion model; tri-generation power plant emission; atmospheric dispersion; NOx; complex topography

\section{Introduction}

The United Nations Framework Convention on Climate Change (UNFCCC) set the ultimate objective to prevent hazardous anthropogenic interference with the climate system.

To meet this goal, the European Commission promotes and supports the reduction in energy consumption, the increase in energy efficiency, the increase in energy production from renewable sources and the reduction in greenhouse gas (GHG) emissions; these commitments were set out in the Directive 2009/29/EC [1], and commonly called European 20-20-20 targets.

To fulfill the purposes of the Directive 2009/29/EC, the European Commission planned preliminary actions, including the promotion of the "cogeneration" [2]. Combined heat and power (CHP) production, or cogeneration, implies that heat and electricity are produced simultaneously in a single process, coupling electricity production technologies with heat recovery equipment [3]. Cogeneration is one of the most promising means of using existing advanced technologies for sustainable energy production. 
$\mathrm{CHP}$ helps to reduce the environmental impact of power generation, because its self-production of electric power reduces the needs of electricity supply from the electric energy network with respect to a traditional power plant. Therefore, the pollutant (mainly $\mathrm{NO}_{\mathrm{x}}, \mathrm{SO}_{\mathrm{x}}$, and $\mathrm{PM}_{10}$ ) and $\mathrm{GHG}$ emissions due to conventional electricity generation, which impact on air quality both at local [4] and at global scale [5], are avoided. Estimates by the European Environmental Agency [6] of the avoided $\mathrm{CO}_{2}$ emissions by the use of CHP led to the classification of cogeneration as a low carbon technology.

For these reasons, environmental policies support the diffusion of cogeneration plants: the share of electricity produced from CHP in the EU-27 is growing since 2008 [7]. Nevertheless, the atmospheric impact of a cogeneration plant must be assessed, and the ground-level concentration of emitted pollutants must be compared with the air quality regulatory limits. That impact depends on the plant emission performance and on the dispersion of its stack emissions in atmosphere, i.e., the meteorological conditions and the local landscape features may also be relevant.

Economic sustainability of CHP plants is strongly influenced by the environmental impact of their atmospheric emissions [8], and therefore, by the topographic setting of plant location. The stack emissions are a key factor in assessing the plant impact on local air quality, but basing this impact simply upon the exhaust mass flow rate of the pollutants and/or its annual atmospheric emissions would lead to partial and inaccurate results. A realistic simulation of pollutant dispersion is needed to properly assess the economic costs of atmospheric impact by the plant. Moreover, the availability of accurate and extended (both in time and space) pollutant concentration fields, having a suitable spatio-temporal resolution, reduces the uncertainty in estimates of population exposure to atmospheric pollution [9].

Several studies based the environmental impact by atmospheric emissions using only statistical models, e.g., Land Use Regression models in urban areas [10] or Geographically Weighted Regression models in larger domains [11]. This type of models fails in estimating the impact by future point emissions, contrarily to dispersion models. Atmospheric dispersion models represent another important tool for atmospheric impact assessment of the stack emissions of power plants. These models allow one to simulate the spatial distribution of pollutants, in order to forecast the impact of an emitting source on air quality, or to identify the contribution of different sources, and support policy strategies for air pollution control.

Very few studies in the literature combined both a statistical and a dispersion model [12], moreover, they generally use simplistic dispersion tools (e.g., Gaussian models), which are based on strong assumptions, and suitable only in rarely occurring conditions. The present study combines the use of a statistical and a dispersion modelling tool, and it is featured by a Lagrangian dispersion model, representing a novelty and providing improved concentration fields for reliable economic assessments of the plant and exposure studies.

The Directive 2008/50/EC [13] and Italian law (D.Lgs. 152 03/04/2006) allow the application of dispersion models for the assessment of air quality, and set the uncertainty which may be applied to a simulation result. The models available are many, featured by different degrees of complexity and different performances. Simulation results produced by different models may not be comparable during some specific atmospheric conditions, such as low winds [14] or local scale winds of breeze, and also over complex topography [15-21].

The development of a natural gas-fired tri-generation power plant (520 MW Combined Cycle Gas Turbines (CCGT) + 58 MW Tri-generation) in the Republic of San Marino, a small independent enclave placed in Northern Italy, is under evaluation. The power plant will have the largest efficiency among all existing plants over the Italian peninsula, it will completely fulfill the energy needs of San Marino, and it will also provide energy to Italy.

The project could benefit from existing and near infrastructures, as gas pipelines and electricity grids export energy to Italy. Moreover, the Italian regions south of San Marino would have a major advantage from the plant, because of the lower number of cogeneration units and the lower electricity production capacity in these areas [22]. The project includes the use of cogeneration in combination 
with heat-pump technology and plug-in vehicles as part of a renewable electric grid, in order to make San Marino a "smart" society [23], with a more robust energy infrastructure which might drive economic growth.

The present work investigates the provisional impact assessment of atmospheric emissions from the cogeneration plant stacks, which could be installed in the Republic of San Marino, in the framework of the regulatory limits put by Italian law (D.Lgs. 152 03/04/2006 and D.Lgs. 46 04/03/2014, implementation of Directive 2010/75/UE [24]). Both technical and socioeconomic aspects of that project have great relevance, yet the environmental implications must be evaluated. Among these, the air pollution caused by the plant emissions, which receive more attention by the population, directly affecting human health.

The study includes simulation results from a Lagrangian dispersion model of the power plant during a worst-case scenario, and three periods well representative of low, moderate, and large atmospheric dispersion conditions, respectively. Only $\mathrm{NO}_{\mathrm{x}}$ and $\mathrm{CO}$ were simulated, being the two compounds having regulatory emission limits for this power plant; since the simulated concentrations of $\mathrm{CO}$ were largely lower than the regulatory limits, the simulation focused only on $\mathrm{NO}_{\mathrm{x}}$. Finally, a statistical analysis of concentration fields has been performed to assess the impact of atmospheric emissions on local air quality, and on exceedance of air quality regulatory limits.

\section{The Cogeneration Plant}

The cogeneration plant considered is the Mitsubishi MHPS GT Model M701F5 and H-25(42) Combined Cycle Gas Turbines (CCGT, $520 \mathrm{MW}$ and $58 \mathrm{MW}$ thermal power respectively) powered by methane gas. The features of the plant and the estimates of $\mathrm{NO}_{x}$ concentrations in the dry exhaust gas (based on $15 \% \mathrm{O}_{2}$ ) for both the CCGT plant units are reported in Table 1 (NOTE: personal communication).

Table 1. Power Plant features, as provided by the manufacturer.

\begin{tabular}{ccccccc}
\hline Unit & $\begin{array}{c}\text { Stack } \\
\text { Height }\end{array}$ & $\begin{array}{c}\text { Stack Inner } \\
\text { Diameter }\end{array}$ & $\begin{array}{c}\text { Exhaust } \\
\text { Gas Flow }\end{array}$ & $\begin{array}{c}\text { Exhaust Gas } \\
\text { Temperature }\end{array}$ & $\begin{array}{c}\text { Gas Exit } \\
\text { Velocity }\end{array}$ & NO $_{\mathbf{x}}$ \\
\hline & $\mathrm{m}$ & $\mathrm{m}$ & $\mathrm{Nm}^{3} \mathrm{~h}^{-1}$ & ${ }^{\circ} \mathrm{C}$ & $\mathrm{m} \mathrm{s}^{-1}$ & $\mathrm{mg} \mathrm{Nm}^{-3}$ \\
M701F5 CCGT & 70 & 6.2 & $1,885,000$ & 85 & 25 & 50 \\
H-25(42) CCGT & 70 & 2.7 & 290,000 & 85 & 20 & 50 \\
\hline
\end{tabular}

Regulatory emission limits are set by the Italian law for combustion plants with nominal thermal power > 50 MW, large combustion plants (D.Lgs. 152 03/04/2006, and D.Lgs. 46 04/03/2014, implementation of Directive 2010/75/UE [24]). Regarding to the new power plants, regulatory limits for Gas Turbines (CCGT included) supplied by methane gas are equal to $30 \mathrm{mg} \mathrm{Nm}^{-3}$ for $\mathrm{NO}_{\mathrm{x}}$ and $100 \mathrm{mg} \mathrm{Nm}^{-3}$ for $\mathrm{CO}$ in dry exhaust gas (based on $15 \% \mathrm{O}_{2}$ ). However, for plants with efficiency greater than $35 \%$, the law (D.Lgs. 46 04/03/2014) sets the emission limit for $\mathrm{NO}_{\mathrm{x}}$ equal to $30 \times \eta(35 \%)$, where $\eta(\%)$ is the efficiency of the plant. For the plant in project, whose efficiency $\eta=61 \%$ (as assured by the Manufacturer), the emission limit for $\mathrm{NO}_{\mathrm{x}}$ results in $52 \mathrm{mg} \mathrm{Nm}^{-3}$.

\section{The Investigation Domain}

The Republic of San Marino (RSM) is an enclave in Italy, on the border between the regions of Emilia Romagna, with the provinces of Forli-Cesena and Rimini, and Marche, with the province of Pesaro-Urbino, at about $10 \mathrm{~km}$ from the Adriatic Sea coast. The country covers an area of about $61.2 \mathrm{~km}^{2}$. It has a Mediterranean climate with mild to cool winters and warm, sunny summers. The Republic of San Marino is affected by land-sea breeze superimposed to a mesoscale circulation. RSM topography is dominated by the Apennine mountain chain, resulting in it being almost completely mountainous ( $83 \%$ of its territory). The highest point in the country is the summit of Mount Titano (749 $\mathrm{m}$ a.s.1.), with the largest town of RSM, San Marino City (4128 inhabitants), that is cited at $625 \mathrm{~m}$ a.s.l. on the 
West side of Mount Titano. The power plant will be installed (as shown in Figure 1a) East of the San Marino City, close to the Italian border, at an elevation of about $120 \mathrm{~m}$ a.s.l.

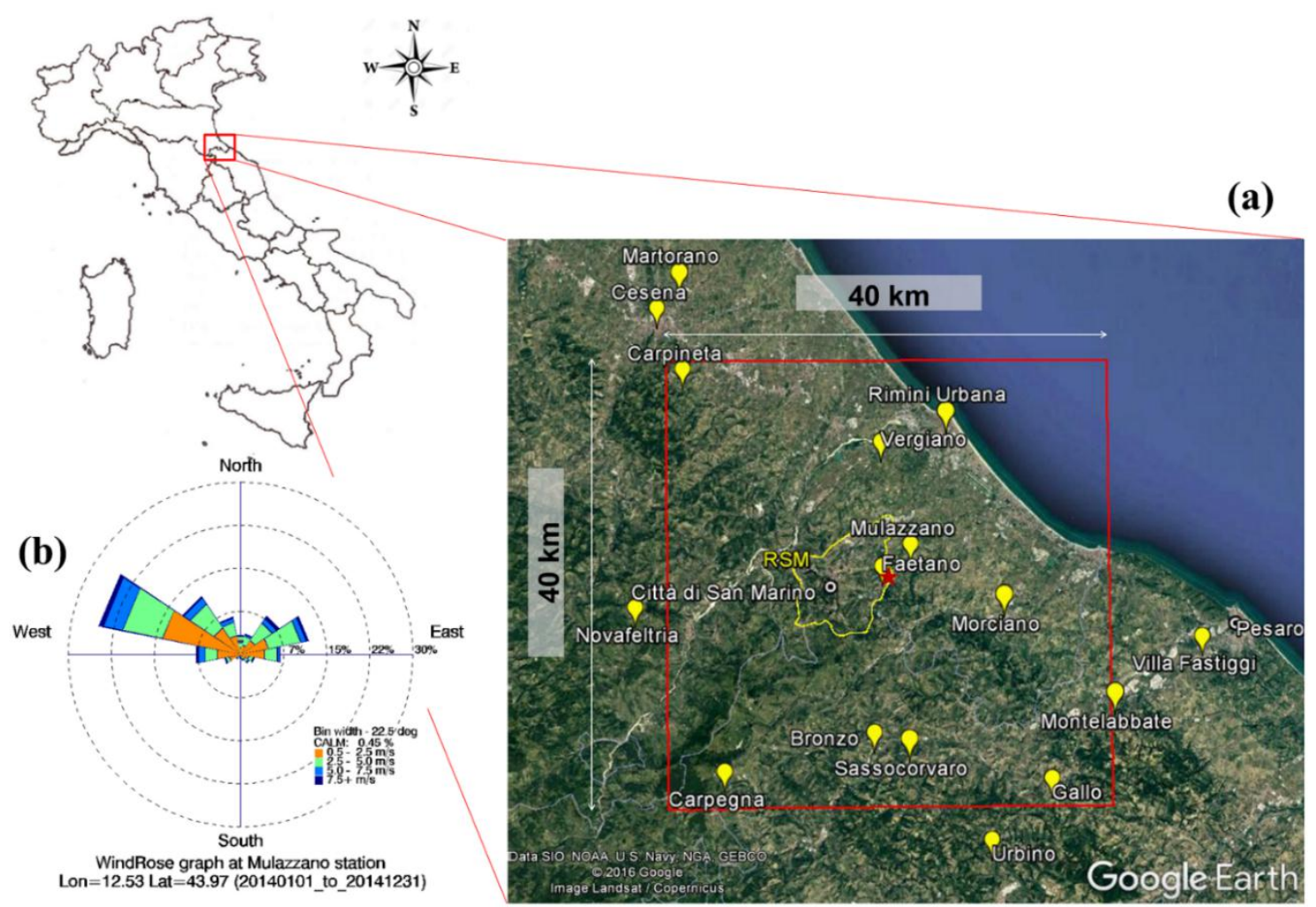

Figure 1. (a) The Republic of San Marino (RSM) is a small enclave in Northern Italy. The investigated domain for the simulation of the atmospheric dispersion of the cogeneration plant stack emissions on a local scale $\left(40 \times 40 \mathrm{~km}^{2}\right)$ extends over the neighbouring regions of Emilia Romagna (north-west) and Marche (south-east). Sixteen ground-based meteorological stations of the Italian Environmental Agency network (yellow pins the in figure), surrounding the power plant site (red star at the domain center) in RSM-as mapped in (a)—were chosen to provide measured meteorological data; (b) Wind rose graph at the meteorological ground station of Mulazzano (hourly wind data), the closest to the source location, for the year 2014.

\section{Software and Datasets}

The simulation of the dispersion of the pollutant emitted by the plant was performed by the software package ARIA INDUSTRY (Arianet srl, Milano, Italy \& ARIA Tehcnologies Boulogne Billancourt, France), which includes the dispersion model SPRAY, the diagnostic wind field meteorological model SWIFT (former MINERVE [25-28]) and the turbulence model SURFPRO [29]. SPRAY is a Lagrangian stochastic model for the simulation of the dispersion of passive pollutants in a complex terrain and non-homogenous conditions, under calm and low wind events [14]. The model operates in non-stationary conditions by approximating temporal variations in successive stationary states. SPRAY gives highly reliable simulations of pollutant dispersion close to the release source point [30,31], and it is able to simulate deposition-decay phenomena. SPRAY supplies a three-dimensional concentration field, vertically subdivided into grid cells at different terrain-following layers, and vertically stretched to obtain higher resolution near the ground.

For the present study, a local scale simulation was performed: the diagnostic wind and temperature fields were computed over the spatial domain of $40 \times 40 \mathrm{~km}^{2}$ (Figure 1a), divided into a horizontal grid of $200 \mathrm{~m}$ square cells, and into a vertical grid of 10 layers from the ground to $1500 \mathrm{~m}$ above ground level. The pollutants concentration fields were computed over two spatial 
domains, the former of $40 \times 40 \mathrm{~km}^{2}$ divided into a horizontal grid of $200 \mathrm{~m}$ square cells, and the latter of $20 \times 20 \mathrm{~km}^{2}$, with a spatial resolution of $100 \mathrm{~m}$. For both, the studied domain is centered at the release source point, i.e., the location of power plant stacks. Each single stack is simulated as an independent emitting source; the stacks have the same location at the simulation spatial scale. For the computation of the pollutant concentration vertical profiles, a vertical grid of 10 layers from the ground to $1500 \mathrm{~m}$ was used. The thickness of the first layer is set to $10 \mathrm{~m}$, starting from the ground level. The emission sources of the power plant were simulated as a non-stop continuous release source points.

Lagrangian models are the used to properly simulate the pollutant dispersion in a complex terrain $[14,15,17,19-21]$ : SPRAY does not include atmospheric photochemical processes, and only few models coupling Lagrangian dispersion with atmospheric chemistry exist in the literature of [32-34]. This study aimed to assess the impact of $\mathrm{NO}_{x}$ stack emissions on local air quality: since regulatory emission limits for combustion plants are set for $\mathrm{NO}_{\mathrm{x}}(2010 / 75 / \mathrm{UE})$, while for air quality are set for $\mathrm{NO}_{2}(2008 / 50 / \mathrm{EC})$, the simulation of $\mathrm{NO}_{\mathrm{x}}$ dispersion represents a conservative and precautionary approach, since $\mathrm{NO}_{\mathrm{x}}$ includes both $\mathrm{NO}_{2}$ and NO. Moreover, the impact of emissions is highest in winter, when photochemistry is at its minimum, consistently with the conservativeness of the approach used, but with a lower simulation bias by neglecting the $\mathrm{NO}_{\mathrm{x}}$ reactivity.

The year 2014 was chosen as reference period, being the most recent year not affected by the El Niño phenomenon. Both experimental and simulated meteorological data were used as input data for the meteorological model. The measured meteorological data were obtained by 16 ground-based meteorological stations of the Italian Environmental Agency network surrounding the power plant site in RSM, as mapped in Figure 1a. The wind rose graph for the meteorological ground station of Mulazzano (the closest to the source), for the year 2014 of hourly-measured wind data is reported in Figure $1 \mathrm{~b}$. The wind rose shows that the wind climate in the site is driven by mesoscale circulation, mainly characterized by moderate winds blowing from North West-West and, with lower frequency, from North East-East.

The simulated input data consist of a vertical wind profile close to the source point provided by the mesoscale COSMO atmospheric model (LAMA dataset), operating by Arpae Emilia Romagna [35,36]. The simulation domain for Italian application of COSMO covers an area of about $2000 \times 2000 \mathrm{~km}^{2}$ with a horizontal resolution of $7 \mathrm{~km}$. The LAMA dataset covers the central part of the COSMO domain, with an area of $1200 \times 1200 \mathrm{~km}^{2}$.

Ground elevation data were provided by the Shuttle Radar Topography Mission through United States Geological Service (USGS), sampled at 3 arc-seconds, with a resolution of about $90 \mathrm{~m}$ (Version 4.1), while the land use/land cover (LULC) dataset was extracted by the European CORINE Land Cover (CLC) 2012 inventory [37]. To fulfill the requirements of SPRAY, the 44 LULC classes provided in the third level classification of the CLC were grouped in 21 classes [38].

\section{Simulation Periods and Meteorological Conditions}

In order to include all typical meteorological situations for the investigation domain, the simulations were performed considering both a period favorable to air pollution buildup (worst-case scenario) and three 10-day periods representative of different atmospheric dispersion conditions for the year 2014. Overall, the study covers two cold season periods featured by meteorological conditions leading to minimal dispersion of pollutants, and two summer periods featured by the highest atmospheric temperatures and maximum dispersion for the test year. This conservative approach is mainly suited to investigate the potential role of stack emissions in the exceedance of air quality regulatory limits (see Table 2 for limits for $\mathrm{NO}_{2}$ and CO, D.Lgs. 155 13/08/2010, implementation of 2008/50/EC [13]). 
Table 2. Air quality limits for $\mathrm{NO}_{2}$ and $\mathrm{CO}$ (D. Lgs. 155 13/08/2010).

\begin{tabular}{ccc}
\hline \multicolumn{3}{c}{ Limit Values for the Protection of Human Health } \\
\hline $\mathrm{NO}_{2}$ & average hourly concentration not to be exceeded more than 18 times a calendar year & $200 \mu \mathrm{g} \mathrm{m}^{-3}$ \\
$\mathrm{NO}_{2}$ & average concentration per calendar year & $40 \mu \mathrm{g} \mathrm{m}^{-3}$ \\
$\mathrm{NO}_{2}$ & alarm threshold: average hourly concentration for 3 consecutive hours & $400 \mu \mathrm{g} \mathrm{m}^{-3}$ \\
$\mathrm{CO}$ & maximum average daily concentration - average over $8 \mathrm{~h}$ & $10 \mathrm{mg} \mathrm{m}^{-3}$ \\
\hline
\end{tabular}

\subsection{The Most Critical Period for Air Quality in 2014}

The air pollution network of Italian Environmental Agency showed that the period between 11th and 20th March 2014 was highly critical for air quality in the neighboring regions of Emilia Romagna and Marche in 2014 [39,40]. In this period, intense anthropogenic emissions combined with adverse meteorological conditions, favoring the air pollution buildup in the first layer of the atmosphere. In March 2014, daily mean $\mathrm{PM}_{10}$ from the air quality network exhibited several exceedances of the daily regulatory limit $\left(50 \mu \mathrm{g} \mathrm{m}^{-3}\right)$, and recorded the annual peak in the nearby provinces of Rimini and Forli-Cesena. By the examination of the origin of air masses with HYSPLIT back-trajectory model [41] during this period, the contribution by Saharan dust from Northern Africa was excluded [42]. Hence, the ten days from March 11th and March 20th 2014 were chosen as the period of investigation of a worst-case scenario.

The main meteorological variables potentially affecting atmospheric pollutant level are: Precipitable Water (PWAT), Wind Speed (WSPD), Temperature (TSFC), and the Planetary Boundary Layer Depth (ZPBL). These parameters were firstly obtained from 6-hourly analysis files from the NOAA National Center for Environmental Prediction (NCEP) Global Forecast System (GFS) [43]. For each day of the investigated period, four analysis files were available at 00, 06, 12, and 18 UTC, calculated at the source coordinate $\left(43.97^{\circ} \mathrm{N}-12.53^{\circ} \mathrm{E}\right)$.

In Figure 2, the trends of ZPBL (a), TSFC (b), and PWAT (c), for the month of March 2014, are reported. This period showed low PBL depth values, including the monthly minimum, mainly during the nighttime, when the PBL decreases due to the lack of rising thermals from the surface. An almost total absence of a cloud cover over the domain, and a total absence of rainfall events, with extremely low precipitable water values (c) was observed during the period. As further relevant consequence of low values of precipitable water, an increment of the air pollution daily mean concentration in the area was recorded.

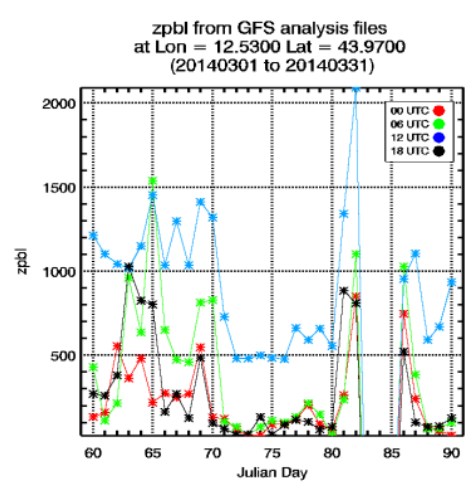

(a)

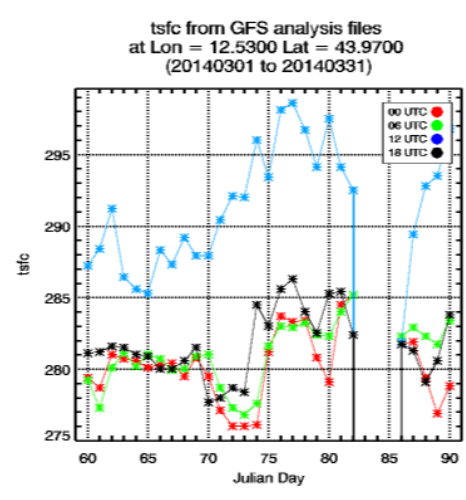

(b)

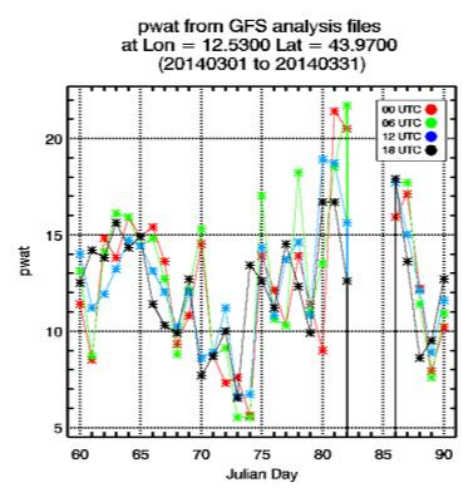

(c)

Figure 2. Time series of the meteorological variables that significantly affect the air quality in the area under investigation and for a specific period of time. (a) Time series trend of the Planetary Boundary Layer Height ZPBL in (m); (b) Surface Temperature TSFC in (K) and (c) Content of Water Precipitable, PWAT in (mm) for the full month of March, 2014. The critical period (March 11th to 20th) corresponds to the Julian Days from 69 to 80 . 
Figure 3a shows the hourly wind rose at the source location for the critical period, obtained from the wind field computed by the diagnostic model SWIFT. The wind rose in Figure $3 b$, shows a sea breeze system featured by winds blowing from W-SW at night, gradually shifting to an E-NE origin at daytime, and wind calm (wind speed $<0.5 \mathrm{~m} \mathrm{~s}^{-1}$ ) after sunset at $18 \mathrm{UTC}$. Wind speeds results were low $\left(0.5-2.5 \mathrm{~m} \mathrm{~s}^{-1}\right)$, except for the first and last day of the period, when they occasionally reached $5 \mathrm{~m} \mathrm{~s}^{-1}$. Frequent wind calms occurred during this period, both after sunset and at night (30\%).

According to the wind roses in Figure 3b, the most notable breeze features are the relatively rapid increase in wind speed from about $1.5 \mathrm{~m} \mathrm{~s}^{-1}$ during the night and early morning hours to about $3 \mathrm{~m} \mathrm{~s}^{-1}$ at 12 UTC. This abrupt wind speed increase is accompanied by a wind shift from a land breeze during the night and a sea breeze during the diurnal hours.

In addition to the meteorological parameters trends analysis, the atmospheric temperature profile by radio-sounding at San Pietro Capofiume was investigated, being the nearest available profile. The data, (not shown) provided by the University of Wyoming, highlighted a thermal inversion at about $1000 \mathrm{~m}$ of altitude at nighttime, during the critical period. This condition of atmospheric stability determined near-surface stagnation and buildup of pollutants.

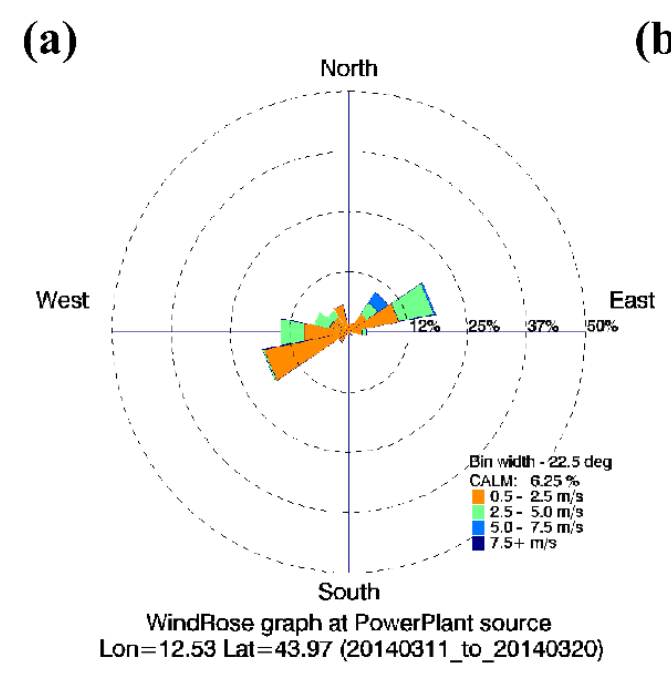

(b) I
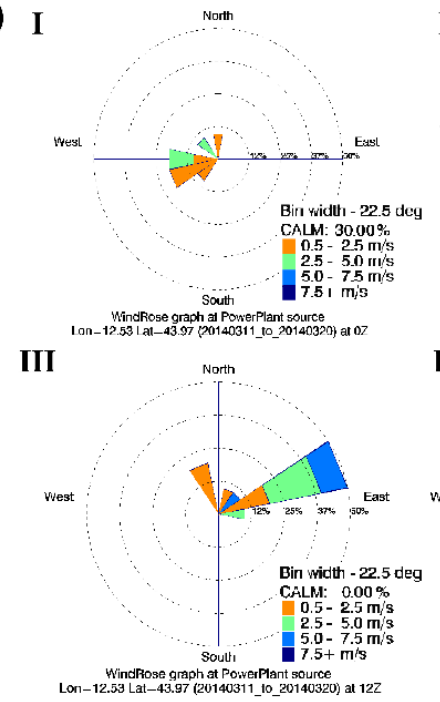

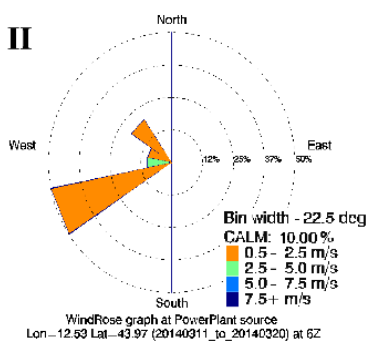

IV

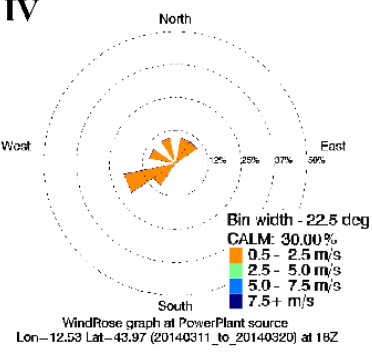

Figure 3. Wind rose graph on the critical period; (a) (March 11th to March 20th, 2014); and (b) calculated at the four synoptic hours: I-00 UTC, II-06 UTC, III-12 UTC, IV-18 UTC of the same period.

\subsection{Summer and Fall Representative Periods during the Year 2014}

The analysis of the atmospheric dispersion included also periods in summer and fall 2014, in order to have a clear picture of the atmospheric dispersion in frequent meteorological conditions. Considering the annual air quality reports for the simulation domain [32,33], it was possible to characterize the summer and the fall periods to be investigated.

Two periods in June 2014 were considered as representative of the summer season. This month is characterized by high values of ZPBL (between 600 and $1900 \mathrm{~m}$ at 12 UTC), more than one consecutive day of sunny days with high temperature at daytime at the surface and few rain episodes. June 6th to June 15th, 2014, and June 19th to June 28th were selected as periods: low PBL depth and high PBL depth occurred in the former and in the latter, respectively. In the second half of June, intense wind speed occurred much more frequently than in the other periods (Figure $4 a, b)$. This meteorological condition, combined with high values of PBL depth, may lead to a good atmospheric dispersion of the emitted pollutants. The summer was featured by a land-sea breeze system similarly to March. 

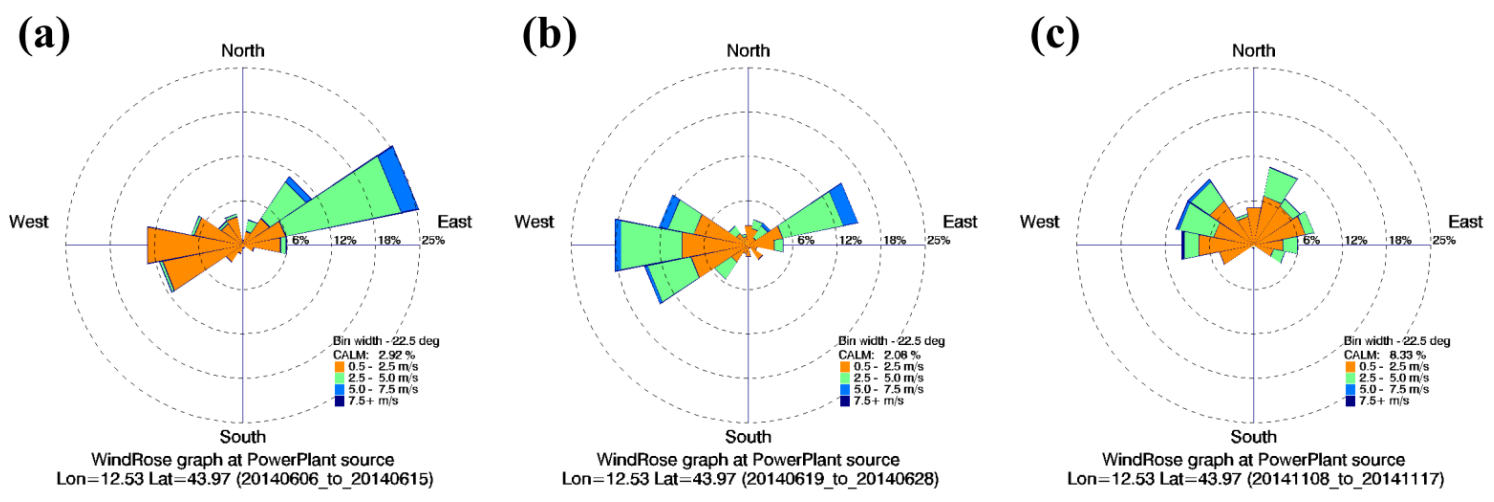

Figure 4. Wind rose graphs on the selected summer periods, (a) (from June 6th to June 15th, 2014); (b) period (from June 19th to June 28th, 2014); and (c) on the selected fall/winter period (from November 8th to November 17th, 2014).

November 2014 was set as a representative period for fall. This period was characterized by low ZPBL from November 8 th to November 17th both at daytime (about $500 \mathrm{~m}$ at 12 UTC), and during the nighttime. Nevertheless, this phenomenon was not observed in the last three days, where the PBL depth reaches about $1000 \mathrm{~m}$ at 12 UTC. In this period the wind at the source point blew mainly from East-Northeast and also from West-Northwest, with speed mainly lower than $5 \mathrm{~m} \mathrm{~s}^{-1}$ (Figure 4c). Calm conditions corresponded to about $8 \%$ of the observations. Intense wind speed $\left(7.5 \mathrm{~m} \mathrm{~s}^{-1}\right)$ events were recorded from Northwest-West. The effect of local sea breeze circulation was not negligible, but it was less evident than in the spring and the summer periods described above.

\section{Results and Discussion}

For each period of analysis, the simulations were performed with an hourly time-step, according to the hourly meteorological input data. The plant was considered under steady-state operation, where its specific features are reported in Table 1.

As introduced in Section 2, the emitted $\mathrm{NO}_{\mathrm{x}}$ concentration in dry exhaust gas (based on $15 \% \mathrm{O}_{2}$ ) was set to $50 \mathrm{mg} \mathrm{N} \mathrm{m}^{-3}$, as provided by the manufacturer, and slightly below the emission limit of $52 \mathrm{mg} \mathrm{Nm}^{-3}$, and $\mathrm{CO}$ concentration in dry exhaust gas (based on $15 \% \mathrm{O}_{2}$ ) was assumed equal to the regulatory limits $\left(100 \mathrm{mg} \mathrm{N} \mathrm{m}^{-3}\right)$.

The simulated concentrations were compared with the air quality limits for $\mathrm{NO}_{2}$, and $\mathrm{CO}$ (D.Lgs. 155 13/08/2010) reported in Table 2. Since the simulated CO ground concentration results were always largely lower than the regulatory limits, they were omitted.

It is worth noting that the maps in Figures 5-7 and all further analysis include only simulated ground concentrations higher than $1 \mu \mathrm{g} \mathrm{m}^{-3}$; these latter concentrations were referred in the rest of the text as plume concentrations. The power plant stacks, due to the map resolution, have the same location at the map scale (red star) and represent the center of the domain.

\section{1. $\mathrm{NO}_{x}$ Average Hourly Concentration Maps for the Most Critical Period}

The simulation was performed at first for the most critical period, ranging from March 11th to March 20th, 2014. Figure 5 shows the maps of the plume emitted by the power plant, as average hourly $\mathrm{NO}_{\mathrm{x}}$ concentration in the first atmospheric layer $(10 \mathrm{~m})$ mapped over the Digital Terrain Model (DTM) of the spatial domain $\left(20 \times 20 \mathrm{~km}^{2}\right.$ in Figure $5 \mathrm{a}$ and $40 \times 40 \mathrm{~km}^{2}$ in Figure $5 \mathrm{~b}$ respectively). The simulated plume in Figure 5a appears stretched approximately from West to East over the $20 \times 20 \mathrm{~km}^{2}$ domain. The simulated $\mathrm{NO}_{\mathrm{x}}$ concentrations were compared to air quality limits for $\mathrm{NO}_{2}$ (Table 2). The average hourly $\mathrm{NO}_{\mathrm{x}}$ concentration in the investigated period ranges from $1 \mu \mathrm{g} \mathrm{m}^{-3}$ to a maximum value of $65 \mathrm{\mu g} \mathrm{m}^{-3}$, at about $5 \mathrm{~km}$ West from the power plant and close to the Mount Titano 
relief. Mount Titano represents a physical barrier to the plume dispersion, causing air stagnation with local accumulation of the power plant emissions. The maximum hourly average concentration $\left(65 \mu \mathrm{g} \mathrm{m}^{-3}\right)$ occurs over the Eastern slope of Mount Titano and next to San Marino City as highlighted in red in Figure 5a. The plume average concentration at ground over the domain is lower than $2 \mu \mathrm{g} \mathrm{m}^{-3}$, largely below the two regulatory limits for hourly peak $\left(200 \mu \mathrm{g} \mathrm{m}^{-3}\right)$ and annual mean $\left(40 \mu \mathrm{g} \mathrm{m}^{-3}\right)$ $\mathrm{NO}_{2}$ concentration. The vertical profiles of $\mathrm{NO}_{\mathrm{x}}$ average hourly concentration along the western plume stretch for the critical period were investigated (not shown). The concentration vertical profiles calculated at 1,3,5, and $10 \mathrm{~km}$ from the release source show the maximum concentration at about $700 \mathrm{~m}$ of altitude, at $5 \mathrm{~km}$ from the source, where the plume impacts the steep slope of the Mount Titano. To better investigate the atmospheric dispersion towards the Adriatic Sea, the concentration field was also computed on a larger domain $\left(40 \times 40 \mathrm{~km}^{2}\right)$, with a horizontal grid step of $200 \mathrm{~m}$. Figure $5 \mathrm{~b}$ shows the maps of average hourly $\mathrm{NO}_{\mathrm{x}}$ ground concentration. The plume concentration for this larger domain were generally lower than the $\mathrm{NO}_{2}$ regulatory limit, ranging from $1 \mu \mathrm{g} \mathrm{m}{ }^{-3}$ to maximum values of about $90 \mathrm{~g} \mathrm{~m}^{-3}$, with an average plume value lower than $2 \mathrm{~g} \mathrm{~m}^{-3}$. In addition to the already mentioned concentration peak $\left(65 \mathrm{~g} \mathrm{~m}^{-3}\right)$ close to the Mount Titano, six non-contiguous cells $\sim 25 \mathrm{~km}$ SE of the plant had a concentration peak of average hourly concentration between $40 \mathrm{~g} \mathrm{~m}^{-3}$ and $90 \mathrm{~g} \mathrm{~m}^{-3}$ (see the red circle in Figure $5 \mathrm{~b}$ ). At that greater distance from the stacks, the plume is dispersed upwards in the atmosphere and downwards to the ground, and natural obstacles (e.g., hills) may cause occasional concentration peaks. The concentration peak on the slope of Mount Titano is due to the recurrent Northeast-East winds, as shown by the wind rose in Figure 4a, while NW winds are responsible for the single scattered peaks occurring South-East of the plant (Figure 5b).
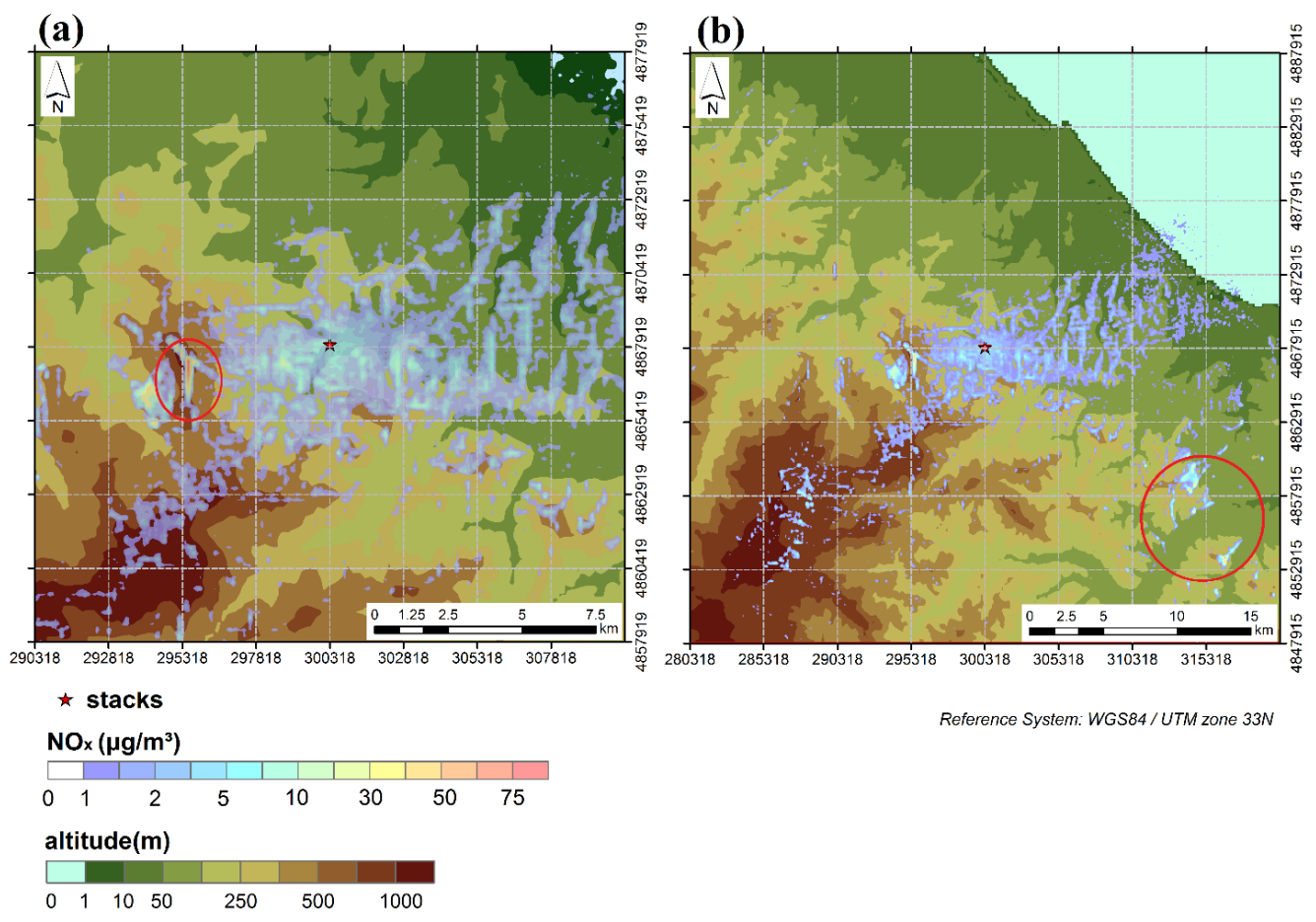

Figure 5. (a) Average hourly $\mathrm{NO}_{x}$ ground concentration plume from the power plant, mapped over the digital terrain model (DTM) spatial domain of $20 \times 20 \mathrm{~km}^{2}$, and (b) average hourly $\mathrm{NO}_{x}$ ground concentration plume from the power plant mapped over DTM of spatial domain $40 \times 40 \mathrm{~km}^{2}$. The color scales refer to $\mathrm{NO}_{\mathrm{x}}$ concentration (top) and to altitude above m.s.l. (bottom). Note that the simulation operates in terrain-following coordinates, then the first atmospheric layer (10 m deep) follows the local terrain height above mean sea level (m.s.l.). The barrier effect of the relief causes concentration maximum values close to Monte Titano and at South-East of the power plant (red circles)-March 11th to March 20th. 


\section{2. $\mathrm{NO}_{x}$ Concentration Maps at the Synoptic Hours}

The wind roses previously reported (Figure $4 \mathrm{~b}$ ) show how the effects of local breeze circulation are important: at the four synoptic hours $(00,06,12,18 \mathrm{UTC})$, a predominant wind direction is evident (see Section 5.1). This effect was investigated on a particular day within the critical period: March 14th, 2014, as the most representative. The maximum average hourly $\mathrm{NO}_{\mathrm{x}}$ ground concentration for March 14th, 2014, was $110 \mathrm{\mu g} \mathrm{m}^{-3}$, and occurred close to the Mount Titano, while the average plume value for the domain is equal to $2.2 \mu \mathrm{g} \mathrm{m}^{-3}$.

The maps of average hourly $\mathrm{NO}_{\mathrm{x}}$ ground concentration at the four synoptic hours $00,06,12,18$ UTC on the spatial domain of $40 \times 40 \mathrm{~km}^{2}$ are reported in Figure $6 \mathrm{a}-\mathrm{c}$. A single map was provided for the two synoptic hours 00 and 06 UTC, due to their similar dominant winds from West-Southwest. At 00 and 06 UTC the plume moves East, while at 12 UTC the plume is transported South by the wind and finally, at 18 UTC, wind calm prevails. It is worth noting that this local sea breeze circulation effect should be considered in combination with the prevailing atmospheric circulation at mesoscale.
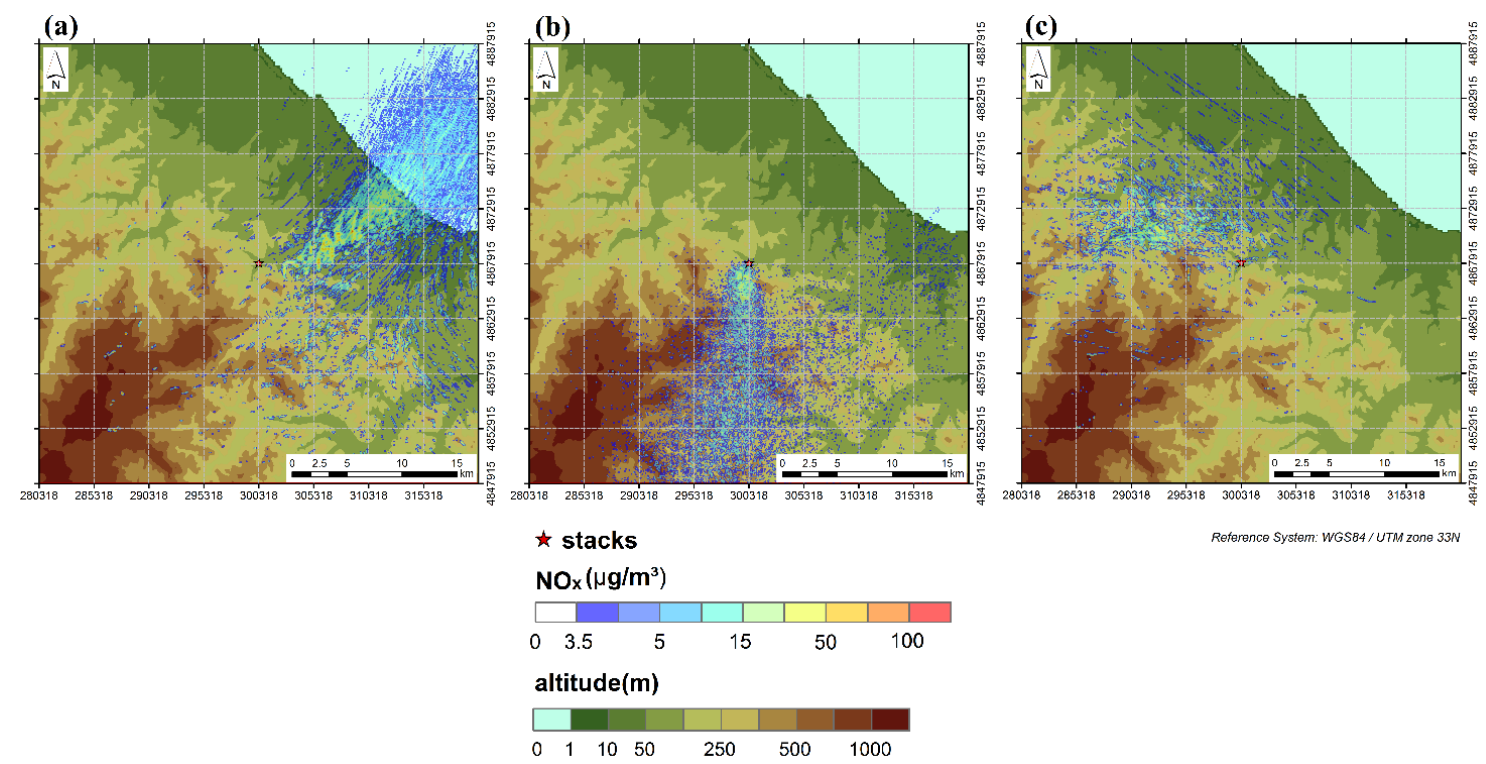

Figure 6. Hourly $\mathrm{NO}_{\mathrm{x}}$ ground concentration plume from the power plant mapped over the DTM spatial domain of $40 \times 40 \mathrm{~km}^{2}$, at (a) 00 UTC; at (b) 12 UTC and at (c) 18 UTC, on March 14th, 2014. The color scales refer to $\mathrm{NO}_{x}$ concentration (top) and to altitude (bottom) above m.s.l. Note that the simulation operates in terrain following coordinates, then the first atmospheric layer (10 $\mathrm{m}$ deep) follows the local terrain height above the m.s.l.

\section{3. $\mathrm{NO}_{x}$ Average Hourly Concentration Maps for the Summer and Fall Periods}

The average hourly $\mathrm{NO}_{\mathrm{x}}$ concentration in the first atmospheric layer $(10 \mathrm{~m})$ in summer (from June 6th to June 15th, 2014 and from June 19th to June 28th, 2014) and in fall (from November 8th to November 17th 2014) periods was simulated considering both the smaller $\left(20 \times 20 \mathrm{~km}^{2}\right)$ and the wider $\left(40 \times 40 \mathrm{~km}^{2}\right)$ domain. The maps for the wider domain are here reported and discussed, as more representative.

Figure 7a shows the maps of the plume emitted by the power plant mapped over the DTM on the wider domain for the first summer period. The plume appears stretched approximately from NE to SW, consistently with the wind rose in Figure 5a, where the much more intense winds blow from Northeast direction. Therefore, the plume is dispersed towards the Mount Titano on the West of the source. The average hourly $\mathrm{NO}_{\mathrm{x}}$ concentration for the plume in this summer period ranges from 
$1 \mu \mathrm{g} \mathrm{m}^{-3}$ to a maximum of $77 \mu \mathrm{g} \mathrm{m}^{-3}$, obtained close to Mount Titano, slightly Southwest from it. The plume average value through the domain is about $2 \mu \mathrm{g} \mathrm{m}^{-3}$.
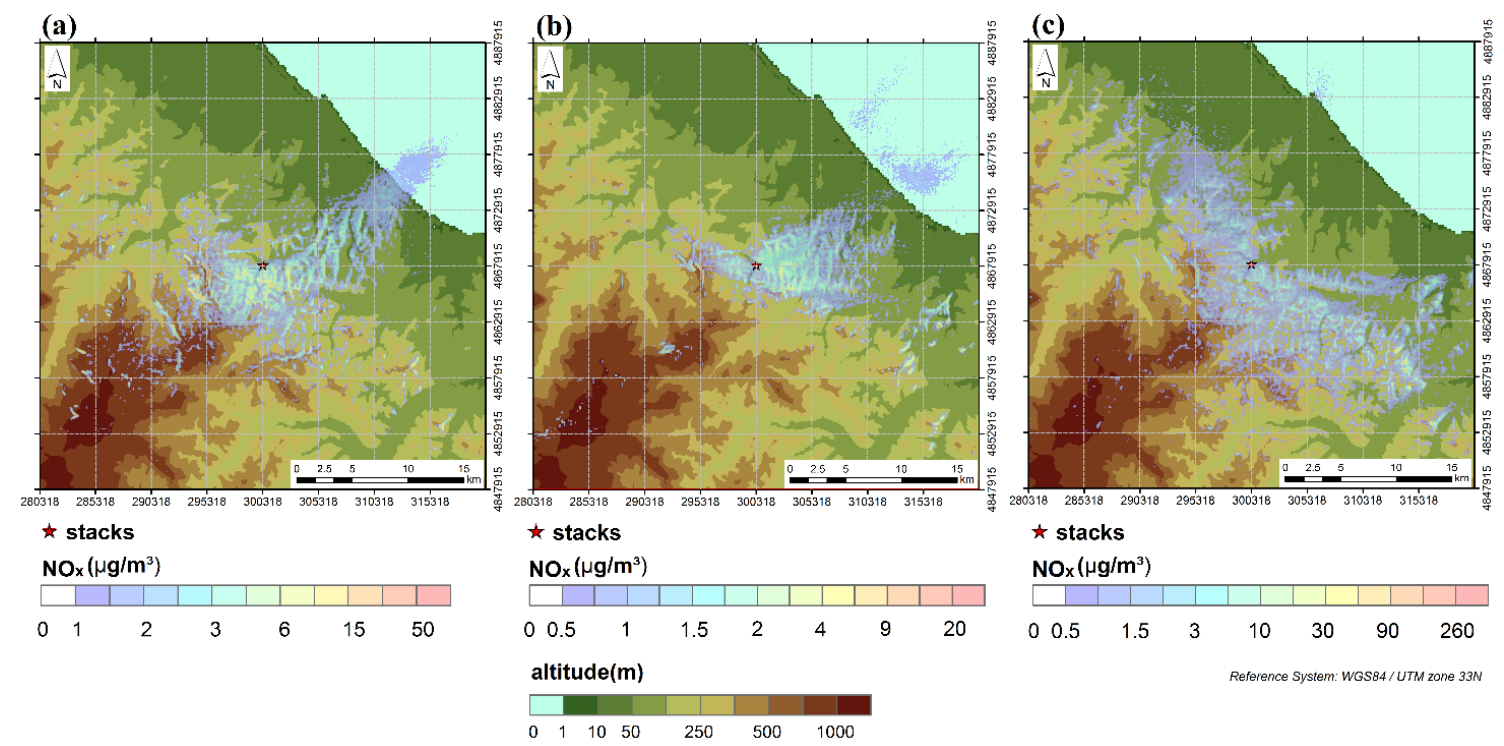

Figure 7. Average hourly $\mathrm{NO}_{\mathrm{x}}$ ground concentration plume from the power plant mapped over DTM of spatial domain $40 \times 40 \mathrm{~km}^{2}$ from (a) June 6th to June 15th; from (b) June 19th to June 28th and from (c) November 8 th to November 17 th. The color scales refer to $\mathrm{NO}_{\mathrm{x}}$ concentration (top) and to altitude (bottom) above m.s.l. Concentration color-bars with different maxima for $(\mathbf{a}-\mathbf{c})$ are used to preserve the resolution of each map.

The plume for the second summer period (Figure $7 \mathrm{~b}$ ), is stretched approximately from West-Northwest to East, consistently with the wind rose in Figure 5b. Since in this period the Western winds are the most intense, the plume is mainly dispersed towards the Adriatic Sea coast. The average hourly $\mathrm{NO}_{x}$ concentration for the plume in this second summer period ranges from $1 \mu \mathrm{g} \mathrm{m}^{-3}$ to a maximum of almost $30 \mu \mathrm{g} \mathrm{m}^{-3}$, occurring at 15-18 $\mathrm{km}$ East South-East of the power plant; concentration values of about $12 \mu \mathrm{g} \mathrm{m}^{-3}$ are obtained on the Eastern slope of Mount Titano relief. The plume average value through the domain is lower than $2 \mu \mathrm{g} \mathrm{m}^{-3}$.

In Figure $7 \mathrm{c}$ the map of the plume for the fall period is shown: the plume is stretched approximately from Northwest to Southeast (see the corresponding wind rose in Figure 5c). In this period, the Northwest-West winds are the most intense, dispersing the plume towards the mountain relieves to the Southeast side of the source. The average hourly $\mathrm{NO}_{\mathrm{x}}$ concentration ranges from $1 \mu \mathrm{g} \mathrm{m}^{-3}$ to a local maximum of almost $390 \mathrm{\mu g} \mathrm{m}^{-3}$, occurring $15 \mathrm{~km}$ Southeast of the power plant. Fifteen non-contiguous domain cells at 20-25 km SE of the plant showed high concentration with an average between $40 \mu \mathrm{g} \mathrm{m}^{-3}$ and $90 \mu \mathrm{g} \mathrm{m}^{-3}$; the area is impacted also during the critical period, when, however, the concentration peaks fall in different domain cells (Section 6.1). Concentrations of about $29 \mu \mathrm{g} \mathrm{m}^{-3}$ are on the Eastern slope of Mount Titano. The plume average value through the domain is about $2 \mu \mathrm{g} \mathrm{m}^{-3}$.

\subsection{Pollution Roses and Exceeding of Regulatory Limits}

The $\mathrm{NO}_{\mathrm{x}}$ pollutant roses for the four simulation periods are shown in Figure 8a-d. The wind data for the source point at the plant stack elevation and the hourly $\mathrm{NO}_{\mathrm{x}}$ ground concentration were used to obtain a conditional bivariate probability function (CBPF [44]): each CBPF estimates the probability that a specific concentration range is observed within a given wind sector (of 5 degrees width), depending upon wind speed. CBPFs in Figure 8 show the probability frequency of $\mathrm{NO}_{\mathrm{x}}$ concentration higher than the hourly regulatory limit for each wind speed and direction class. 
CBPFs were computed using wind data by the diagnostic model SWIFT at the source point, and the average simulated $\mathrm{NO}_{\mathrm{x}}$ concentration in a $100 \mathrm{~m} \times 700 \mathrm{~m}$ area over the Eastern slope of Mount Titano, where recurrent concentration peaks are expected. The concentration range used to compute CBPF considered levels larger than the regulatory limit of $200 \mathrm{\mu g} \mathrm{m}^{-3}$. Plots in Figure 8 show that in March (Figure 8a), the exceedances are triggered by moderate Eastern winds, in June (Figure 8b,c) exceedances have a very low probability, and in November, the exceedances over that small area of the Eastern slope of Mount Titano are related to wind calm and slow Northestern winds.

The outcome of CBPF was compared to the wind roses of each investigated period (Figures 3a and $4 a-c)$ : CBPFs show the percentage of wind conditions that may be responsible of concentration peaks around the Mount Titano area, while the wind rose graph for the entire year 2014 (Figure 1b) shows that the frequency of the wind events blowing from Northeast-East in the year 2014 is of about $11 \%$, while the calms correspond to less than $1 \%$ in the year. Therefore, the regulatory limit for average hourly $\mathrm{NO}_{2}$ concentration is expected to be exceeded more than 18 times a calendar year, but limited to the focus area on the Eastern slope of Mount Titano. Considering only the simulation periods, in the focus area, the regulatory limit for $\mathrm{NO}_{2}$ is exceeded 33 times in total (14 times in March, 13 in November, 2 and 4 in the two summer periods respectively). Nonetheless, in the nearby domain cells, $\mathrm{NO}_{\mathrm{x}}$ concentration sharply decreases, with results largely lower than the regulatory limits. Consistently with CBPF (Figure 8), the 33 exceedances occur in presence of wind events blowing from Northeast-East and of wind calms.
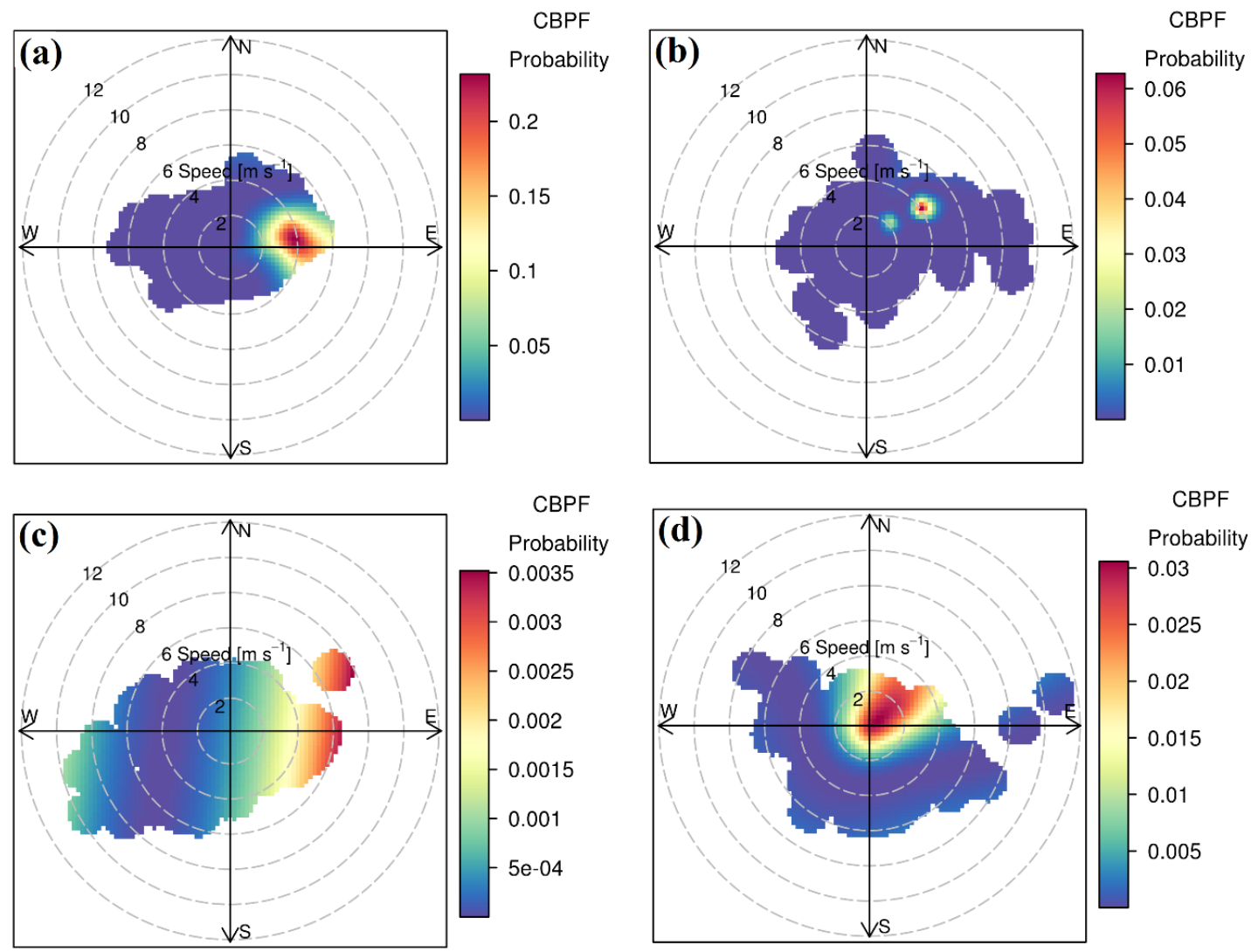

Figure 8. Conditional Bivariate Probability Functions (CBPF) for $\mathrm{NO}_{\mathrm{x}}>200 \mu \mathrm{g} \mathrm{m}^{-3}$ during the four simulation periods: March (a), June (b,c), and November $(\mathbf{d})$. CBPF were computed using wind data by the diagnostic model SWIFT at the source point, and the average simulated $\mathrm{NO}_{\mathrm{x}}$ concentration in a $100 \times 700 \mathrm{~m}^{2}$ area over the Eastern slope of Mount Titano where recurrent concentration peaks are expected. CBPF color bars with different maxima for $(\mathbf{a}-\mathbf{d})$ are used to preserve the resolution of each plot. 


\section{Conclusions}

The present work investigated the impact assessment of the $\mathrm{NO}_{\mathrm{x}}$ atmospheric emissions from a cogeneration plant, which will be installed in the area of Republic of San Marino, considering the regulatory limits for the combustion plants set by the Italian law. The environmental impact was performed via numerical simulations of atmospheric dispersion of the exhaust gases emitted from the cogeneration plant stacks and the results further analyzed by statistical models. The study considered both a worst-case meteorological scenario (critical period) in March 2014, and two summer and one fall representative period in 2014. The power plant was assumed under continuous non-stop operation. The resulting maps of hourly average simulated concentration at the ground level (i.e., in the first atmospheric layer starting from the ground, $10 \mathrm{~m}$ thick) showed values largely lower than the regulatory limits for air quality for $\mathrm{NO}_{2}$.

The results of the simulations for the largest of the two simulation domains $\left(40 \times 40 \mathrm{~km}^{2}\right)$, both for the critical and the representative periods, showed at the ground level average hourly concentration fields featured by very low values, with local single peaks where the emission plume impacts the ground reliefs. These peaks occur in two different areas of the domain depending on the simulation period: an area over the SE slope of Mount Titano showing recurrently large concentration levels both in March and in the June periods, and an area at 20-25 km SE of the power plant. Peaks in this latter area occur in different domain cells depending on the simulation period, without the evidence of a recurring accumulation point, therefore, they should not give rise to persistent pollutant buildups.

Nevertheless, the $\mathrm{NO}_{x}$ plume average concentration over the largest investigated is ca. $2 \mu \mathrm{g} \mathrm{m}^{-3}$. The wind rose graph for the entire year 2014 showed that the frequency of NE winds causing a concentration peaks over the slope of Mount Titano was of about $11 \%$, and that the frequency of NW winds causing high concentration SE from the power plant is of about $12 \%$, while wind calm frequency is lower than $1 \%$ per year. The pollution roses show that the regulatory limit for average hourly $\mathrm{NO}_{2}$ concentration is already exceeded more than 18 times during the investigated period, but limited to a steep area on the cliff of Mount Titano. Therefore, the power plant emissions are expected to meet the air quality limit for $\mathrm{NO}_{2}$ hourly average concentration $\left(200 \mu \mathrm{g} \mathrm{m}^{-3}\right)$ throughout the investigated domain, except around the area close to Mount Titano, where the hourly limit for $\mathrm{NO}_{2}$ is expected to be exceeded. Due to its location with respect to the source, this area may be considered the most exposed to a local accumulation of pollutants emitted from the power plant. Yet, it is fortunately not a residential area, due to its steep morphology. Similarly, the power plant emissions will be expected to meet the annual limit $\left(40 \mathrm{\mu g} \mathrm{m}^{-3}\right)$ for mean annual $\mathrm{NO}_{2}$ throughout the investigated domain, except around the area close to Mount Titano. The limit for $\mathrm{NO}_{2}$ annual mean is expected not to be exceeded in the area SE of the power plant, even if several concentration peaks occur there, because these single peaks (in scattered domain cells) mainly occur in different areas of the domain for each simulated period, without the evidence of recurring accumulation points.

This study highlighted how the innovative combined use of a Lagrangian dispersion model (SPRAY) and of statistical models leads to an accurate assessment of the environmental impact by power plant emissions over a complex terrain and under unsteady wind conditions. The project includes the use of cogeneration in combination with heat-pump technology and plug-in vehicles, as part of a renewable electric grid, in order to make San Marino a "smart" society [23], with a more robust energy infrastructure which might drive economic growth.

Acknowledgments: Authors are thankful to Italian agencies Arpae Emilia-Romagna, Arpa Marche for providing ground level PM10 data, the European Environment Agency for providing CORINE Land Cover 2000 and to USGS for providing SRTM DEM data. The views, opinions, and findings contained in this report are those of the authors.

Author Contributions: G. Ghermandi conceived and designed the experiment, and wrote the paper. S. Fabbi and G. Veratti performed the simulation of the dispersion. B. Arvani and S. Teggi retrieved, preprocessed and analyzed the meteorological data. A. Bigi performed the statistical analysis.

Conflicts of Interest: The authors declare no conflict of interest. 


\section{References}

1. The European Parliament and the Council of the European Union. The European Parliament and the Council of Europe Directive 2009/29/EC of 23 April 2009 Amending Directive 2003/87/EC so as to Improve and Extend the Greenhouse Gas Emission Allowance Trading Scheme of the Community (Text with EEA Relevance). Available online: http:/ / eur-lex.europa.eu/legal-content/en/TXT/?uri=CELEX:32009L0029 (accessed on 9 November 2017).

2. The European Parliament and the Council of the European Union. The European Parliament and the Council of Europe Directive 2004/8/EC of 11 February 2004 on the Promotion of Cogeneration Based on a Useful Heat Demand in the Internal Energy Market and Amending Directive 92/42/EEC. Available online: http:/ / eur-lex.europa.eu/legal-content/EN/ ALL/?uri=CELEX:32004L0008 (accessed on 9 November 2017).

3. Dharmadhikari, S. Consider trigeneration techniques for process plants. Hydrocarb. Process. 1997, 76, 91-100.

4. Levy, J.I.; Spengler, J.D. Modeling the Benefits of Power Plant Emission Controls in Massachusetts. J. Air Waste Manag. Assoc. 2002, 52, 5-18. [CrossRef] [PubMed]

5. Intergovernmental Panel on Climate Change (IPCC). Climate Change 2014: Synthesis Report; Contribution of Working Groups I, II and III to the Fifth Assessment Report of the Intergovernmental Panel on Climate Change; Pachauri, R.K., Meyer, L.A., Eds.; Intergovernmental Panel on Climate Change (IPCC): Geneva, Switzerland, 2014.

6. European Environmental Agency. Energy Efficiency in Transformation (ENER 011); European Environmental Agency: Copenhagen, Denmark, 2017.

7. European Environmental Agency. Combined Heat and Power (CHP) (ENER 020); European Environmental Agency: Copenhagen, Denmark, 2012.

8. Aliehyaei, M.; Atabi, F.; Khorshidvand, M.; Rosen, M.A. Exergy, Economic and Environmental Analysis for Simple and Combined Heat and Power IC Engines. Sustainability 2015, 7, 4411-4424. [CrossRef]

9. Vallero, D.A. Air Pollution Monitoring Changes to Accompany the Transition from a Control to a Systems Focus. Sustainability 2016, 8. [CrossRef]

10. Hu, L.; Liu, J.; He, Z. Self-Adaptive Revised Land Use Regression Models for Estimating PM2.5 Concentrations in Beijing, China. Sustainability 2016, 8. [CrossRef]

11. Fang, C.; Liu, H.; Li, G.; Sun, D.; Miao, Z. Estimating the Impact of Urbanization on Air Quality in China Using Spatial Regression Models. Sustainability 2015, 7, 15570-15592. [CrossRef]

12. Tashayo, B.; Alimohammadi, A.; Sharif, M. A Hybrid Fuzzy Inference System Based on Dispersion Model for Quantitative Environmental Health Impact Assessment of Urban Transportation Planning. Sustainability 2017, 9. [CrossRef]

13. The European Parliament and the Council of the European Union. The European Parliament and the Council of Europe Directive 2008/50/EC of 21 May 2008 on ambient air quality and cleaner air for Europe. Available online: http:/ / eur-lex.europa.eu/legal-content/en/ALL/?uri=CELEX:32008L0050 (accessed on 9 November 2017).

14. Ghermandi, G.; Teggi, S.; Fabbi, S.; Bigi, A.; Cecchi, R. Model comparison in simulating the atmospheric dispersion of a pollutant plume in low wind conditions. Int. J. Environ. Pollut. 2012, 48, 69-77. [CrossRef]

15. Bellasio, R.R. Bianconi The LAPMOD modelling system for simulating atmospheric pollution in complex orography. Ing. Ambient. 2012, 41, 492-500. (In Italian)

16. Brusasca, G.; Carboni, G.; Finardi, S.; Sanavio, D.; Tinarelli, G.; Toppetti, A. Comparison of a Gaussian (ISC3) and a Lagrangian Particle Model (SPRAY) for Regulatory applications in Flat and Complex Terrain Sites Representative of Typical Italian Landscape. In Proceedings of the 7th International Conference on Harmonization within Atmospheric Dispersion Modelling for Regulatory Purposes, Belgirate, Italy, 28-31 May 2001.

17. Davakis, E.; Nychas, S.G.; Andronopoulos, S.; Bartzis, J.G. Validation study of the dispersion Lagrangian particle model DIPCOT over complex topographies using different concentration calculation methods. Int. J. Environ. Pollut. 2003, 20, 33-46. [CrossRef]

18. Gariazzo, C.; Pelliccioni, A.; Bogliolo, M.P.; Scalisi, G. Evaluation of a Lagrangian Particle Model (SPRAY) to Assess Environmental Impact of an Industrial Facility in Complex Terrain. Water Air Soil Pollut. 2004, 155, 137-158. [CrossRef]

19. Nanni, A.; Riva, G.M.; Tinarelli, G.; Brusasca, G. Particle model simulation of pollutants dispersion from a line source in complex terrain. Sci. Total Environ. 1996, 189, 301-309. [CrossRef] 
20. Oettl, D. A multiscale modelling methodology applicable for regulatory purposes taking into account effects of complex terrain and buildings on pollutant dispersion: A case study for an inner Alpine basin. Environ. Sci. Pollut. Res. 2015, 22, 17860-17875. [CrossRef] [PubMed]

21. Pession, G.; Zublena, M.; Agnesod, G.; Brusasca, G.; Calori, G.; Nanni, A.; Finardi, S.; Silibello, C.; Tinarelli, G. Use of 3D Atmospheric Dispersion Modelling for Air Quality Management in a Very Complex Terrain Alpine Region (Valle d'Aosta). In Proceedings of the 10th International Conference on Harmonization within Atmospheric Dispersion Modelling for Regulatory Purposes, Crete, Greece, 17-20 October 2005.

22. Gestore dei Servizi Energetici. Statistical Report on Cogeneration. Reference Period 2013; Gestore dei Servizi Energetici (GSE S.p.A.): Roma, Italy, 2014. (In Italian)

23. Hara, M.; Nagao, T.; Hannoe, S.; Nakamura, J. New Key Performance Indicators for a Smart Sustainable City. Sustainability 2016, 8. [CrossRef]

24. The European Parliament and the Council of the European Union. The European Parliament and the Council of Europe Directive 2010/75/EU of 24 November 2010 on Industrial Emissions (Integrated Pollution Prevention and Control) Text with EEA Relevance. Available online: http://eur-lex.europa.eu/legalcontent/EN/TXT/?uri=celex:32010L0075 (accessed on 9 November 2017).

25. ARIA Technologies. SWIFT Wind Field Model, General Design Manual; ARIA Technologies: Livermore, CA, USA, 2010.

26. Cox, R.M.; Sontowski, J.; Dougherty, C.M. An evaluation of three diagnostic wind models (CALMET, MCSCIPUF, and SWIFT) with wind data from the Dipole Pride 26 field experiments. Meteorol. Appl. 2005, 12, 329-341. [CrossRef]

27. Geai, P. Methode D'Interpolation et de Reconstitution Tridimensionelle d'un Champ de Vent: Le Code D'Analyse Objective MINERVE; EDF: Chatou, France, 1987.

28. Moussafir, J.; Olry, C.; Castanier, P.; Tinarelli, G.; Perdriel, S. Applications of the mss (Micro-SWIFT-SPRAY) model to long-term regulatory simulations of the impact of industrial plants. In Proceedings of the 13th International Conference on Harmonization within Atmospheric Dispersion Modelling for Regulatory Purposes, Paris, France, 1-4 June 2010.

29. Finardi, S.; Morselli, M.G.; Brusasca, G.; Tinarelli, G. A 2-D meteorological pre-processor for real-time 3-D ATD models. Int. J. Environ. Pollut. 1997, 8, 478-488. [CrossRef]

30. Ghermandi, G.; Fabbi, S.; Zaccanti, M.; Bigi, A.; Teggi, S. Micro-scale simulation of atmospheric emissions from power-plant stacks in the Po Valley. Atmos. Pollut. Res. 2015, 6, 382-388. [CrossRef]

31. Ghermandi, G.; Teggi, S.; Fabbi, S.; Bigi, A.; Zaccanti, M.M. Tri-generation power plant and conventional boilers: Pollutant flow rate and atmospheric impact of stack emissions. Int. J. Environ. Sci. Technol. 2014, 12, 693-704. [CrossRef]

32. Alessandrini, S.; Ferrero, E. A hybrid Lagrangian-Eulerian particle model for reacting pollutant dispersion in non-homogeneous non-isotropic turbulence. Phys. A Stat. Mech. Appl. 2009, 388, 1375-1387. [CrossRef]

33. Alessandrini, S.; Ferrero, E. A Lagrangian particle model with chemical reactions: Application in real atmosphere. Hrvat. Meteoroloski Cas. 2008, 43, 235-239.

34. Oettl, D.; Uhrner, D. Development and evaluation of GRAL-C dispersion model, a hybrid Eulerian-Lagrangian approach capturing $\mathrm{NO}-\mathrm{NO}_{2}-\mathrm{O}_{3}$ chemistry. Atmos. Environ. 2011, 45, 839-847. [CrossRef]

35. Marsigli, C.; Boccanera, F.; Montani, A.; Paccagnella, T. The COSMO-LEPS mesoscale ensemble system: Validation of the methodology and verification. Nonlinear Process. Geophys. 2005, 12, 527-536. [CrossRef]

36. Montani, A.; Cesari, D.; Marsigli, C.; Paccagnella, T. Seven years of activity in the field of mesoscale ensemble forecasting by the COSMO-LEPS system: Main achievements and open challenges. Tellus A 2011, 63, 605-624. [CrossRef]

37. European Environment Agency. Copenhagen, Denmark. Corine Land Cover (CLC) 2012, Version 18.5.1. Available online: http://land.copernicus.eu/pan-european/corine-land-cover/clc-2012 (accessed on 19 November 2017).

38. Teggi, S.; Bogliolo, M.P.; Ghermandi, G.; Fabbi, S.; Funaro, M.; Gariazzo, C. Surface parameters evaluated from satellite remote sensing images for pollutant atmospheric dispersion modelling. Croat. Meteorol. J. 2008, 43, 421-425.

39. Arpae Emilia Romagna. Relazione RRQA 2014; Annual Report; Advanced Research Projects Agency-Energy (ARPA-E): Washington, DC, USA, 2014. 
40. Arpae Emilia Romagna. La Qualità Dell'aria in Provincia Di Rimini Nel 2014; Annual Report; Advanced Research Projects Agency-Energy (ARPA-E): Washington, DC, USA, 2014.

41. Stein, A.F.; Draxler, R.R.; Rolph, G.D.; Stunder, B.J.B.; Cohen, M.D.; Ngan, F. NOAA's HYSPLIT Atmospheric Transport and Dispersion Modeling System. Bull. Am. Meteorol. Soc. 2015, 96, 2059-2077. [CrossRef]

42. Israelevich, P.; Ganor, E.; Alpert, P.; Kishcha, P.; Stupp, A. Predominant transport paths of Saharan dust over the Mediterranean Sea to Europe. J. Geophys. Res. Atmos. 2012, 117. [CrossRef]

43. National Centers for Environmental Prediction (NCEP); National Weather Service (NWS); National Oceanic and Atmospheric Administration (NOAA); U.S. Department of Commerence. NCEP GFS 0.25 Degree Global Forecast Grids Historical Archive. Available online: https:/ / rda.ucar.edu/datasets/ds084.1/ (accessed on 9 November 2017).

44. Uria-Tellaetxe, I.; Carslaw, D.C. Conditional bivariate probability function for source identification. Environ. Model. Softw. 2014, 59, 1-9. [CrossRef]

(C) 2017 by the authors. Licensee MDPI, Basel, Switzerland. This article is an open access article distributed under the terms and conditions of the Creative Commons Attribution (CC BY) license (http://creativecommons.org/licenses/by/4.0/). 